\title{
Haematological values in homozygous sickle cell disease in steady state and haemoglobin phenotypes AA controls in Lagos, Nigeria
}

\author{
${\text { Akinsegun Akinbami }{ }^{1 *}, \text { Adedoyin Dosunmu }^{1}, \text { Adewumi Adediran }^{3}, \text { Olajumoke Oshinaike }^{2} \text {, Phillip Adebola }}^{2}$ \\ and Olanrewaju Arogundade
}

\begin{abstract}
Background: Sickle cell disease is a genetic abnormality involving the haemoglobin. Although, it is primarily a red cell disorders, the white blood cells and platelets are also affected by the mutation. The consequent haemoglobin $S$ causes polymerization of haemoglobin resulting in haemolysis and anaemia. This study aims to provide baseline haematological values in sickle cell disease patients in steady state and compare the deviation from haemoglobin phenotype AA control values.

Methods: A case-control study was conducted amongst homozygous sickle cell patients attending the sickle cell clinics of Lagos State University Teaching Hospital Ikeja and haemoglobin phenotype AA controls. About 4.5mls of blood sample was collected from each participant for full blood count analysis. All blood samples were screened for HIV and haemoglobin phenotypes confirmed using cellulose acetate haemoglobin electrophoresis at pH 8.6.

Results: A total of 103 cases and 98 controls were enrolled. The overall mean haemoglobin concentration for cases was $7.93 \pm 1.47 \mathrm{~g} / \mathrm{dl}$, packed cell volume $24.44 \pm 4.68 \%$, mean cell volume $81.52 \pm 7.89 \mathrm{fl}$, and mean cell haemoglobin $26.50 \pm 3.20 \mathrm{pg}$. While for controls, mean haemoglobin concentration was $13.83 \pm 1.32 \mathrm{~g} / \mathrm{dl}$, packed cell volume $43.07 \pm 3.95 \%$, mean cell volume $86.90 \pm 4.69 \mathrm{fl}$, and mean cell haemoglobin $28.50 \pm 1.34 \mathrm{pg}$. The overall mean white blood cell counts for the cases was $10.27 \pm 3.94 * 10^{3} / \mu$ and platelet counts of $412.71 \pm 145.09^{*} 10^{3} / \mu \mathrm{l}$. While white blood cell count for the controls was $5.67 \pm 1.59^{*} 10^{3} / \mu$ l and platelet counts of $222.82 \pm 57.62^{*} 10^{3} / \mu$ l.

Conclusion: Homozygous sickle cell disease patients have lower values of red cell parameters, but higher values of white cell and platelets counts compared to haemoglobin phenotype AA controls.
\end{abstract}

Keywords: Haematological values, Homozygous sickle cell disease, Steady state, Haemoglobin phenotype AA

\section{Background}

Sickle cell disease is a genetic abnormality involving the haemoglobin. Patients present with a wide spectrum of disorders because of a single-point mutation in which thymine substitute for adenine, thereby encoding valine instead of glutamine in the sixth position of the betachain. Haemoglobin S resulting from the substitution causes polymerization of haemoglobin and red cell sickling on exposure to low oxygen tension and unsickle on oxygenation.

\footnotetext{
* Correspondence: ajoke_clinic@yahoo.co.uk

'Department of Haematology and Blood Transfusion, Lagos State University, College of Medicine, Lagos, Nigeria

Full list of author information is available at the end of the article
}

The repeated sickling and unsickling damages the red cell membrane leading to irreversibly sickled red cell even when the oxygen pressure is increased thus reducing red cell life span as a result of membrane damage inducing anaemia. The white blood cells and platelets are also affected by the mutation.

\section{Red blood cells in sickle cell disease}

Quantitative and qualitative changes in red blood cells have been reported. Haemolysis consequent to the damaged red cell membrane could be intravascular or extravascular. The former results from the lysis of complement-sensitive red cells [1] and haemoglobin lost during sickling-induced membrane damaged. [2,3] The

\section{Biomed Central}


latter, occurs by phagocytosis of red cells that have undergone sickling $[4,5]$ and physical entrapment of rheologically compromised red cells.[6] Increased susceptibility to mechanically induced cell fragmentation has been documented in-vitro and in sickle cell patients undergoing vigorous exercise [3].

Degree of haemolysis is inversely related to haemoglobin concentration and packed cell volume in sickle cell anemia patient [7]. Numerous factors affect haemolysis in sickle cell anaemia, percentage of irreversible sickle cell is of greatest significance. [7] The degree of haemoglobin polymer formation, calculated from the mean corpuscular haemoglobin concentration and the relative proportion of haemoglobin fractions also correlates closely with the severity of haemolysis. $[8,9]$.

\section{White blood cells in sickle cell disease}

Although sickle cell disease is primarily a disease of the red blood cell, leucocytes, because of their sizes obstruct blood vessels more effectively than red blood cells when attached to the endothelium. The red blood cells measures $7.2 \mu \mathrm{m}$, while small lymphocytes measures $10 \mu \mathrm{m}$, neutrophils 10-14 $\mu \mathrm{m}$, large lymphocytes $12-16 \mu \mathrm{m}$, monocytes 14-20 $\mu \mathrm{m}$. Bacterial infection associated with leucocytosis is a known predisposing factor to sickle cell disease crises $[10,11]$. A high absolute neutrophil count showed statistically significant relationship with clinical severity of sickle cell anaemia [12].

Many complications of sickle cell disease are associated with leucocytosis. It is a risk factor for early sickle cell disease -related death. [13] It is implicated in clinically overt stroke $[14,15]$.

Pathogenesis of silent cerebral infarction [16] and acute chest syndrome [17] have been associated with leucocytosis.

\section{Platelets in sickle cell disease}

Unlike the red and white blood cells, the clinical effects of platelets on sickle cell disease are not well established [18]. However, an association between stroke in sickle cell disease and platelet count $>450,000 / \mu \mathrm{l}$ has been reported [19]. Qualitatively, poor platelet aggregation responses to epinephrine and ADP were also reported in sickle cell disease [20].

The objective of this study was to provide baseline haematological values in sickle cell anaemia patients in steady state and compare deviation of these parameters from normal controls with haemoglobin phenotypes AA.

\section{Methods}

A case-control study was conducted amongst Sickle cell patients in steady state attending the sickle cell clinics of Lagos State University Teaching Hospital Ikeja (LASUTH) referred from private clinics outside the hospital and other clinics in the hospital and whose diagnoses were confirmed by alkaline haemoglobin electrophoresis and controls consisting of medical students, doctors and nurses of the institution between September to December 2011 after obtaining approval from LASUTH, the institution's Ethics and Research Committee. Written and verbal consents were obtained from each participant.

\section{Study design}

Sickle cell patients filled validated structured questionnaires including demographic information, history of previous blood transfusion, and surgery, previous history of crises, date of last crises, cigarettes and alcohol intake. Inclusion criteria were; patients with haemoglobin phenotype SS, no history of crises in the past 3 months established by a careful history and complete physical examination, no previous history of surgery, no history of blood transfusion in the past 3 months. Exclusion criteria were; history of blood transfusion in the past 3 months, haemoglobin phenotype SC patients, previous history of surgery, and HIV infected patients.

All controls were phenotype AA as confirmed by $\mathrm{Hb}$ electrophoresis and were asked to fill questionnaires containing demographic information. Controls with haemoglobin phenotype AS or SC were excluded from the study. All patients were on routine tablets used in the sickle cell clinics i.e. folic acid ,paludrine and vitamin B complex tablets, none of them was on hydroxyurea therapy which could impact on the reported results for the patient group.

\section{Collection of samples}

A blood sample of $4.5 \mathrm{mls}$ was collected from both patients and controls into Ethylene Diamene Tetraacetic acid (EDTA) anticoagulant bottle for full blood count analysis done on the same day of collection using Sysmex KN-21 N,(manufactured by Sysmex corporation Kobe, Japan) a three- part auto analyzer able to run 19 parameters per sample including haemoglobin concentration, packed cell volume, red blood cell concentration, mean corpuscular haemoglobin, mean cell volume, mean corpuscular haemoglobin concentration, white blood cells and platelet parameters.

\section{Procedure}

Well mixed blood sample was aspirated, by letting the equipment sampling probe into the blood sample and then pressing the start button. Approx. 20ul of blood was aspirated by the auto analyzer. Result of analysis is displayed after about 30secs.A printout copy of result is released on the thermal printing paper.

All blood samples were also screened for HIV using determine rapid kit [21], and haemoglobin phenotypes 
of all patients and controls were confirmed using cellulose acetate haemoglobin electrophoresis at $\mathrm{pH}$ 8.6. About $50 \mathrm{ul}$ of EDTA blood samples of patients and controls were lysed with equal volume of water and haemoglobin separated out with carbon tetrachloride. Lysed samples of patients and controls and known AA, AS, SC, and SS controls were placed on cellulose acetate paper in batches using an applicator. The paper was placed in electrophoretic tank containing tris-buffer, $\mathrm{pH}$ 8.6,electric current was applied. All samples and AA, AS, SC, and SS controls samples migrated from negative to positive pole at 400volt. Haemoglobin separation occurs within 4-6minutes, haemoglobin bands were compared with the known controls.

\section{Statistical analysis}

Data were analyzed using SPSS version 16.0 (Statistical Package for Social Sciences, Inc., Chicago, Ill). The descriptive data were given as means \pm standard deviation (SD. The Pearson chi squared test was used for analytic assessment and the differences were considered to be statistically significant when the $\mathrm{p}$ value obtained was $<0.05$.

\section{Results}

Demographic characteristics of cases and controls

A total of 103 cases and 98 controls were enrolled. Cases consisted of 57 (55.33\%) females and 46 (44.66\%) males, while controls were made up of $68(69.38 \%)$ females and 30 (30.61\%) males (Table 1).

Table 1 Gender, age and background information of participants

\begin{tabular}{|c|c|c|c|c|}
\hline \multirow[t]{2}{*}{ Parameters } & \multicolumn{2}{|c|}{ Cases } & \multicolumn{2}{|c|}{ Controls } \\
\hline & Males & Females & Males & Females \\
\hline Frequency & $46(44.66 \%)$ & $57(55.33 \%)$ & $30(30.61 \%)$ & $68(69.38 \%)$ \\
\hline Mean age $\pm S D$ & $22.62 \pm 6.93$ & $24.72 \pm 8.37$ & $28.74 \pm 9.47$ & $31.18 \pm 10.49$ \\
\hline \multirow{2}{*}{$\begin{array}{l}\text { Overall Mean } \\
\text { age } \pm \text { SD }\end{array}$} & $23.79 \pm 7.81$ & $30.43 \pm 10.19$ & & \\
\hline & Frequency & Percent & & \\
\hline \multicolumn{5}{|l|}{ Bone pain crises } \\
\hline Yes & 94 & 91.2 & & \\
\hline No & 9 & 8.73 & & \\
\hline Total & 103 & 100 & & \\
\hline \multicolumn{5}{|c|}{ Cigarette smoking } \\
\hline Yes & 1 & 0.97 & & \\
\hline No & 102 & 99.03 & & \\
\hline Total & 103 & 100 & & \\
\hline \multicolumn{5}{|l|}{ Alcohol intake } \\
\hline Yes & 11 & 10.67 & & \\
\hline No & 92 & 89.32 & & \\
\hline Total & 103 & 100 & & \\
\hline
\end{tabular}

The overall mean age of the cases was $23.79 \pm 7.81$ years, and control was $30.43 \pm 10.19$ years. The minimum age of cases was 14 and maximum of 44 years and for controls were 17 years and 57 years respectively. All participants tested negative to HIV antibodies.

\section{Hematological indices in study population}

For cases, the overall mean haemoglobin concentration was $7.93 \pm 1.47 \mathrm{~g} / \mathrm{dl}$, packed cell volume $24.44 \pm 4.68 \%$, mean cell volume $81.52 \pm 7.89 \mathrm{fl}$, mean cell haemoglobin $26.50 \pm 3.20 \mathrm{pg}$, and mean cell haemoglobin concentration $32.50 \pm 1.07 \mathrm{~g} / \mathrm{dl}$. While for controls, mean haemoglobin concentration was $13.83 \pm 1.32 \mathrm{~g} / \mathrm{dl}$, packed cell volume $43.07 \pm 3.95 \%$, mean cell volume $86.90 \pm 4.69 \mathrm{fl}$, mean cell haemoglobin $28.50 \pm 1.34 \mathrm{pg}$, and mean cell haemoglobin concentration $32.06 \pm 0.90 \mathrm{~g} / \mathrm{dl}$ (Table 2).

The mean haemoglobin concentration of the male cases was $8.11 \pm 1.53 \mathrm{~g} / \mathrm{dl}$, packed cell volume $25.04 \pm 4.90 \%$, mean cell volume $81.71 \pm 6.34 \mathrm{fl}$, mean cell haemoglobin $26.54 \pm 2.46 \mathrm{pg}$, mean cell haemoglobin concentration $32.45 \pm 1.00 \mathrm{~g} / \mathrm{dl}$, and male controls mean haemoglobin concentration was13.83 $\pm 1.32 \mathrm{~g} / \mathrm{dl}$, packed cell volume $43.07 \pm 3.95 \%$, mean cell volume $86.90 \pm 4.69 \mathrm{fl}$, mean cell haemoglobin $28.25 \pm 1.34 \mathrm{pg}$ and mean cell haemoglobin concentration $32.06 \pm 0.90 \mathrm{~g} / \mathrm{dl}$. For the female cases the mean haemoglobin concentration was $7.78 \pm 1.42 \mathrm{~g} / \mathrm{dl}$, packed cell volume $23.95 \pm 4.49 \%$, mean cell volume $81.36 \pm 9.01 \mathrm{fl}$, mean cell haemoglobin $26.47 \pm 3.71 \mathrm{pg}$, mean cell haemoglobin concentration $32.54 \pm 1.08 \mathrm{~g} / \mathrm{dl}$. For female controls mean haemoglobin concentration was11.96 $\pm 3.10 \mathrm{~g} / \mathrm{dl}$, packed cell volume $36.59 \pm 3.30 \%$, mean cell volume $84.63 \pm 8.82 \mathrm{fl}$, mean cell haemoglobin $27.20 \pm 1.92 \mathrm{pg}$, mean cell haemoglobin concentration $31.59 \pm 0.93 \mathrm{~g} / \mathrm{dl}$ (Table 2).

Majority of the cases 62 of $103(60.2 \%)$ had packed cell volume between $20-30 \%$, followed by 29 of 103 (28.2\%) who had values less than $20 \%$ and only 12 of 103 (11.7\%) had values greater than $30 \%$. Almost all the controls 97 of 98 (99\%) had packed cell volume greater than $30 \%$. While only 1 of 98 (1\%) had a value less than $30 \%$.

For the cases, the overall mean white blood cell counts was $10.27 \pm 3.94 * 10^{3} / \mu \mathrm{l}$ and platelet counts of $412.71 \pm 145.09 * 10^{3} / \mu \mathrm{l}$. While the overall mean white blood cell count for the controls was $5.67 \pm 1.59 * 10^{3} / \mu \mathrm{l}$ and platelet counts of $222.82 \pm 57.62 * 10^{3} / \mu \mathrm{l}$. The mean white blood cell for males cases was $10.82 \pm 4.95^{*} 10^{3} / \mu \mathrm{l}$ and platelet counts $408.40 \pm 133.42 * 10^{3} / \mu$ l and the mean white blood cell count for females cases was $9.83 \pm 2.86$ $* 10^{3} / \mu \mathrm{l}$ and platelet counts of $416.12 \pm 155.09 * 10^{3} / \mu \mathrm{l}$. The mean white blood cell count for males controls was $5.75 \pm 1.63 * 10^{3} / \mu \mathrm{l}$, and platelet counts of $239.00 \pm 62.25$ and the mean white blood cell count for females 
Table 2 Mean values of full blood count parameters

\begin{tabular}{|c|c|c|c|c|c|c|}
\hline \multirow[t]{2}{*}{ Parameters } & \multicolumn{3}{|c|}{ Cases } & \multicolumn{3}{|c|}{ Controls } \\
\hline & Males & Females & Overall & Males & Females & Overall \\
\hline $\mathrm{Hgb} \mathrm{g} / \mathrm{dl}$ & $8.11 \pm 1.53$ & $7.78 \pm 1.42$ & $7.93 \pm 1.4$ & $13.83 \pm 1.32$ & $11.96 \pm 3.10$ & $13.83 \pm 1.32$ \\
\hline PCV\% & $25.04 \pm 4.90$ & $23.95 \pm 4.49$ & $24.44 \pm 4.68$ & $43.07 \pm 3.95$ & $36.59 \pm 3.30$ & $43.07 \pm 3.95$ \\
\hline $\mathrm{MCV} f \mathrm{l}$ & $81.71 \pm 6.34$ & $81.36 \pm 9.01$ & $81.52 \pm 7.89$ & $86.90 \pm 4.69$ & $84.63 \pm 8.82$ & $86.90 \pm 4.69$ \\
\hline $\mathrm{MCH}$ pg & $26.54 \pm 2.46$ & $26.47 \pm 3.71$ & $26.50 \pm 3.20$ & $28.25 \pm 1.34$ & $27.20 \pm 1.92$ & $28.50 \pm 1.34$ \\
\hline $\mathrm{MCHCg} / \mathrm{dl}$ & $32.45 \pm 1.00$ & $32.54 \pm 1.08$ & $32.52 \pm 1.07$ & $32.06 \pm 0.90$ & $31.59 \pm 0.93$ & $32.06 \pm 0.90$ \\
\hline WBC & $10.82 \pm 4.95$ & $9.83 \pm 2.86$ & $10.27 \pm 3.94$ & $5.75 \pm 1.63$ & $5.63 \pm 1.59$ & $5.67 \pm 1.59$ \\
\hline Plts & $408.40 \pm 133.42$ & $416.21 \pm 155.09$ & $412.71 \pm 145$ & $239 \pm 62.25$ & $222.15 \pm 58.03$ & $222.82 \pm 57$ \\
\hline
\end{tabular}

Abbreviations: Hgb-haemoglobin concentration, PCV--Packed cell volume, MCV-Mean cell volume, MCH-Mean cell haemoglobin, MCHC-Mean cell haemoglobin concentration, WBC-White blood cells*10\%/, Plts-Platelets* $10^{9} / \mathrm{l}$.

controls was $5.63 \pm 1.59$; and platelet counts of $222.15 \pm 58.03$ (Table 2).

Most of the cases 71 of 103 (68.9\%) had white blood cell count less than $12,000 / \mu$ l but a substantial number, 32 of 103 (31.1\%) had white blood cell count more than $12,000 / \mu \mathrm{l}$. Only 1 of 98 controls (1\%) had white blood cell count more than $12,000 / \mu$ l. Cross tabulating white blood cell count with frequency of bone pain showed no statistically significant relationship p value $=0.322$.

Almost half of the cases 43 of 103 (41.8\%) had platelet count greater than $450,000 / \mu \mathrm{l}$, while 60 of $103(58.3 \%)$ had platelet count less than $450,000 / \mu \mathrm{l}$. None of the controls had platelet count greater than $450,000 / \mu \mathrm{l}$. A statistically significant relationship was found between platelet counts and packed cell volume of the subjects $\mathrm{p}=0.001$ (Table 3).

\section{Discussion}

This study highlights haematologic reference ranges of homozygous sickle cell patients compared with normal controls with haemoglobin phenotypes AA. The red cell indices were generally lower in sickle cell patients than controls with haemoglobin phenotype AA while the white blood cells and platelet counts were higher than control values. These results were expected considering the degree of chronic haemolysis, higher risk of infections and chronic pain in sickle cell patients. Most

Table 3 Bivariate analysis of degree of anaemia with platelet counts in cases

\begin{tabular}{lcccc}
\hline & $\begin{array}{c}\text { High Platelets }> \\
\mathbf{4 5 0 , 0 0 0 / \mu l}\end{array}$ & $\begin{array}{c}\text { Normal Platelets } \\
\mathbf{< 4 5 0 , 0 0 0 / \mu l}\end{array}$ & Total & P value \\
\hline PCV & 17 & 12 & 29 & 0.00 \\
Low $<20 \%$ & 25 & 37 & 62 & \\
Moderate $20-30 \%$ & 1 & 11 & 12 & \\
Normal $>30 \%$ & 43 & 60 & 103 & \\
Total & & &
\end{tabular}

Abbreviation. PCV-Packed cell volume. patients have adapted to low red cell indices; there is therefore no clinical benefit to treat anaemia with blood transfusion. On the contrary, raising the packed cell volume to over $30 \%$ could increase blood viscosity, which increases with high packed cell volume [22].

Pain may be responsible for the leucocytosis seen in sickle cell anaemia. The overall mean white blood cells count of $10.27 \pm 3.94 * 10^{3} / \mu$ l amongst homozygous sickle cell disease patients doubles value obtained in HbAA controls $5.67 \pm 1.59 * 10^{3} / \mu$ l. Due to re-distribution of the white cells between the marginal and circulating pools, pain, nausea and vomiting and anxiety have been reported to cause leucocytosis in the absence of infection.[23] Although, a statistically significant relationship could not be established in this study between white blood cell count and frequency of pain. Undoubtedly, leucocytosis is associated with poor prognosis, [10-17] while reducing neutrophil count is associated with good prognosis. The benefit of hydroxyurea therapy in sickle cell anaemia follows a fall in neutrophil count, even in patients who have no increase in haemoglobin F [24]

Secondly, and more importantly, leucocytosis in sickle cell disease patients may due to auto splenectomy resulting from recurrent splenic vessels occlusion, which make patients more vulnerable to overwhelming infections particularly, encapsulated organisms like Streptococcus pneumonia and Haemophilus influenzae.[25]

Despite the controls recruitment being un-intentionally skewed towards female gender who constituted $70 \%$ of the volunteers, the overall mean of haemoglobin concentration and packed cell volume of controls $13.83 \pm 1.32 \mathrm{~g} /$ $\mathrm{dl}$ and $43.07 \pm 3.95 \%$ respectively almost doubles that of cases $7.93 \pm 1.47 \mathrm{~g} / \mathrm{dl}$ and $24.44 \pm 4.68 \%$ respectively. The rate of chronic haemolysis associated with sickle cell anaemia patients could account for these lower values. There is also a blunted response to erythropoietin secretion in sickle cell anaemia; the rate of increase is not proportional to the degree of anaemia [26]. This may be due to rightshifted haemoglobin dissociation curve seen in sickle cell disease [27]. Similarly lower values were obtained by 
Omoti in Benin city, Nigeria [28] amongst homozygous sickle cell disease patients in steady state.

The mean cell volume, mean cell haemoglobin, and mean cell haemoglobin concentration are all reduced in anaemia of chronic disease. Expectedly, the mean haemoglobin concentration, packed cell volume, mean cell volume, and mean cell haemoglobin of the controls were higher than cases and males higher than females in both cases and controls. The effects of anaemia of chronic disease, infections and haemolysis could account for lower values seen in cases compared to controls.

Also, confounding factors like cigarette smoking and alcohol intake were ruled out in the cases because insignificant number of them gave history of cigarette smoking and alcohol intake. Increased erythropoesis due to androgens in males, and iron loss or blood loss in females during menstruation may be responsible for higher levels of the red cell indices in males. Reference ranges for erythropoietin are however, not different between the sex. [29] A negative feedback effect on erythropoietin production in males resulting in lower erythropoietin levels would have been expected because of the androgen effect. This indicates that females have better tissue oxygenation for a given haemoglobin level and more efficient tissue red cell delivery.

The overall mean platelet counts for the cases were $412.71 \pm 145.09^{*} 10^{3} / \mu \mathrm{l}$ and for the controls $222.82 \pm 57.62 * 10^{3} / \mu$ l which is almost $100 \%$ higher in cases compared to controls. A negative feedback effect on erythropoietin production in subjects as a result of the anaemia could be responsible for the thrombocytosis. Erythropoietin has a structural homology with thrombopoetin, although the latter is considerably larger than the former but roughly half of thrombopoetin has identity with or similarity to erythropoietin at the Nterminal region. [30] It is therefore, well recognized that thrombocytosis is associated with anaemia of chronic disease and several types of anaemia.

Reduced or absent splenic sequestration of platelets as a result of hyposplenism in sickle cell disease also contribute significantly to higher mean platelet counts in sickle cell disease compared with controls. [31] This study provides haematologic reference ranges for homozygous sickle cell disease patients compared with normal controls in Lagos, Nigeria. It is our hope, physicians involved in managing sickle cell anaemia patients would become more informed and make use of the findings in this study in their practice.

\section{Conclusion}

Homozygous sickle cell disease patients have lower values of Haemoglobin concentration, packed cell volume, red cell indices, but higher values of white cell count and platelets compared to haemoglobin phenotype AA controls.

\section{Competing interests}

The authors declare that they have no competing interests.

\section{Acknowledgement}

We are grateful to Mr. Wale Dally who bled the patients for the tests and Dr. Adelekan Oluwaseun who recruited them.

\section{Author details}

'Department of Haematology and Blood Transfusion, Lagos State University, College of Medicine, Lagos, Nigeria. ${ }^{2}$ Department of Medicine, Lagos State University, College of Medicine, Lagos, Nigeria. ${ }^{3}$ Department of Haematology and Blood Transfusion, Faculty of Clinical Sciences, College of Medicine, University of Lagos, Lagos, Nigeria.

\section{Authors' contribution}

A.A.A Conceptualized and designed the study. Did the data entry and analysis. D.A.O Drafted the manuscript and revised it critically for important intellectual content. A.A Made substantial contributions to conception and design of the manuscript and revised before final submission. O.O Was involved in the drafting of the manuscript and revised it critically for important intellectual content. A.O - Carried out the full blood count analysis. Dr. A.P - Revised the manuscript critically for important intellectual content and gave final approval of the version to be published. All authors read and approved the final manuscript.

\section{Limitations of the study}

1. All sickle cell cases were diagnosed by only haemoglobin electrophoresis using alkaline buffer. There is no facility to confirm the diagnosis in the centre, some of them might have thalassaemia trait e.g. SBthal which could impact on RBC count, MCV, and haemoglobin concentration.

2. Female patients or controls were not screened for iron deficiency. Presence of iron deficiency in either patients or controls could impact on observed results.

3. Lower haemoglobin in the females may be due to menstrual blood loss. 4. Patients were also not screened for hepatitis B and C infections, known complications of blood transfusion which could induce cytopenias in them. 5. Reliability on background information provided by patients.

6. Lack of case-control matching.

Received: 17 March 2012 Accepted: 25 July 2012

Published: 1 August 2012

\section{References}

1. Test ST, Kleman K, Lubin B: Characterisation of the complement sensitivity of density-fractionated sickle cells. Blood 1991, 78(Suppl):202a.

2. Allan D, Lumbrick AR, Thomas P, Westerman MP: Release of Spectrin-free Spicules on re- oxygenation of sickled erythrocytes. Nature 1982, 295(5850):612-613.

3. Platt OS: Exercise-induced haemolysis in Sickle cell anaemia: Shear sensitivity and erythrocyte dehydration. Blood 1982, 59(5):1055-1060.

4. Galili U, Clark MR, Shohat SB: Excessive binding of natural anti-alpha galactosyl immunoglobulin $\mathrm{G}$ to sickle erythrocytes may contribute to extravascular cell destruction. J Clin Invest 1986, 77(1):27-33.

5. Green GA, Kalra VK: Sickling-induced binding of immunoglobulin to sickle erythrocyte. Blood 1988, 71(3):636-639.

6. Kaul DK, Fabry ME, Nagel RL: Vaso-Occlusion by Sickle cells, evidence from selective trapping of dense red cells. Blood 1986, 68(5):1162-1166.

7. Serjeant GR, Serjeant BE, Milner PF: The irreversibly sickled cell, a determinant of haemolysis in sickle cell anaemias. Br J Haematol 1969, 17(6):527-533.

8. Noguchi $C T$, Schechter AN: Non-uniformity of intracellular polymer formation in sickle erythrocytes, possible correlation with severity of haemolytic anaemia. Annu. Rev. Biophys. Chen. 1985, 4:239.

9. Brittenham GM, Schechter AN, Noguchi CT: Haemoglobin S polymerization: primary determinant of the haemolytic and clinical severity of sickling syndromes. Blood 1985, 65(1):183-189.

10. Okpala IE: The management of crises in sickle cell disease (review). Eur J Haematol 1998, 68:1-6. 
11. Attah EB, Ekere MC: Death patterns in sickle cell anaemia. JAMA 1987, 233:890-899.

12. Anyaegbu CC, Okpala IE, Aken'ova AY, Salimonu LS: Peripheral blood neutrophil count and candidacidal activity correlate with the clinical severity of sickle cell anaemia. Eur J Haematol 1998, 60:267-8.

13. Platt OS, Brambilla DJ, Rosse WF, et al: Mortality in sickle cell disease-life expectancy and risk factors for early death. N Engl J Med 1994, 330:1639-1643.

14. Ohene-frempong K, Weiner SJ, Sleeper LA, et al: Cerebrovascular accidents in sickle cell disease;rates and risk factors. Blood 1998, 91:288-294.

15. Powers DR: Management of cerebral vasculopathy in children with sickle cell anaemia. Br J Haematol 2000, 108:666-678.

16. Kinney TR, Sleeper LA, Wang WC, et al: Silent cerebral infarcts in sickle cell anaemia: a risk factor analysis. Paediatrics; 1999, 103:640-645.

17. Castro O, Brambilla DJ, Thorington B, et al: The acute chest syndrome of sickle cell disease; Incidence and risk factors. The co-operative study of sickle cell disease. Blood 1994, 84:643-645.

18. Okpala I: Steady-state platelet count and complications of sickle cell disease. The Haematology Journal 2002, 3:214-215.

19. Miller ST, Sleeper LA, Pegalow CH, et al: Predictions of adverse outcomes in children with sickle cell disease; a report from the cooperative study (CSSCD). N Engl J Med 2000, 342:83-89.

20. Mehta P, Mehta J: Abnormalties of platelet aggregation in sickle cell disease. J Pediatr 1980, 96(2):209-213.

21. Arai H, Petchalai B, Khupulsup K, Kurimura T, Takeda K: Evaluation of Rapid Immunochromatographic Test for Detection of Antibodies to Human Immunodefficiency Virus. J Clin Microbiol 1999, 37(2):367-370.

22. Kaul DK, Fabry M, Windisch P, Baez S, Nagel R: Erythrocytes in sickle cell anaemia are heterogenous in their rheological and haemodynamic characteristics. J Clin Invest 1983, 72:22-31.

23. Milhorat AT: Leucocytosis during various emotional states. Arch Neurol Psych. 1942, 47:779.

24. Charache S, Terrin ML, Moore RD, et al: Effect of hydroxyurea on the frequency of painful crises in sickle cell anaemia. N. Engl. Med 1995, 322:1314-1322.

25. Oloopoenia L, Fredrick W, Greaves W, Adams R, et al: Pneumococcal sepsis and meningitis in adults with sickle cell disease. South Med J 1990, 83:1002-1004

26. Sherwood JB, Goldwesser E, Chilcoat R, et al: Sickle cell anaemia patients have low erythropoietin levels for their degree of anaemia. Blood 1987, 67:46-49.

27. Morris J, Dunn D, Beckford M, et al: The haematology of homozygous sickle cell disease after 40. Br J Haematol 1991, 77:382-385.

28. Omoti CE: Haematological values in sickle cell anaemia in steady state and during vaso-occlusive crises in Benin city,Nigeria. Ann Afr Med 2005, 4(2):62-67.

29. Kraff-Jacobs B, Williams J, Soldin SJ: Plasma erythropoietin reference ranges in children. The journal of Paediatrics 1995, 126(4):601-603.

30. Hoffbrand AV, Lewis MS, Tuddenham ED: Postgraduate Haematology. 4th edition. Madison Avenue, New York Inc.: Oxford University Press; 2001:19.

31. Schwartz AD: The splenic platelet reservoir in sickle cell anaemia. Blood 1972, 40(5):678.

\section{doi:10.1186/1756-0500-5-396}

Cite this article as: Akinbami et al.: Haematological values in

homozygous sickle cell disease in steady state and haemoglobin phenotypes AA controls in Lagos, Nigeria. BMC Research Notes 2012 5:396.

\section{Submit your next manuscript to BioMed Central and take full advantage of:}

- Convenient online submission

- Thorough peer review

- No space constraints or color figure charges

- Immediate publication on acceptance

- Inclusion in PubMed, CAS, Scopus and Google Scholar

- Research which is freely available for redistribution 